\title{
Pemodelan Aliran 1D pada Bendungan Tugu Menggunakan Software HEC-RAS
}

\author{
Sintya Maghfira Ismawati, Dr. Techn. Umboro Lasminto, S.T., M.Sc. \\ Jurusan Teknik Sipil, Fakultas Teknik Sipil dan Perencanaan, Institut Teknologi Sepuluh Nopember \\ Jl. Arief Rahman Hakim, Surabaya 60111 Indonesia \\ e-mail: sintyamaghfira@gmail.com,umboro_hydro@yahoo.com
}

\begin{abstract}
Abstrak - Dalam perencanaan bangunan air khususnya perencanaan bendungan dilakukan suatu perhitungan aliran untuk mendapatkan profil muka air. Perhitungan aliran tersebut menggunakan konsep steady atau unsteady flow. Perhitungan steady flow dapat dilakukan secara analitis sehingga diperoleh aliran seragam, sementara untuk perhitungan unsteady flow diperlukan suatu program bantu guna untuk mempermudah perhitungan, salah satu program bantu yang dapat digunakan adalah HEC-RAS. Program HECRAS merupakan salah satu program pemodelan analisis hidraulika aliran pada saluran/sungai.

Pemodelan aliran dengan HEC-RAS pada Bendungan Tugu dapat disimulasikan menjadi 2 cara. Cara 1 yaitu dengan memodelkan waduk sebagai River Station dan bendungan sebagain Inline Structure. Sementara untuk cara ke 2, waduk dimodelkan sebagai Storage Area dan bendungan sebagai Inline Structure. Pemodelan geometri pelimpah dapat disimulasikan ke dalam kedua pemodelan tersebut. Hasil dari beberapa pemodelan tersebut salah satunya yaitu profil permukaan air, hasil inilah yang digunakan untuk membandingkan dengan hasil perhitungan analitis.

Dari hasil beberapa pemodelan yang telah dilakukan diperoleh elevasi muka air waduk pada kondisi debit periode ulang 1000 tahun sebesar $+\mathbf{2 5 6 . 0 7}$ (pemodelan cara 1), dengan debit yang sama untuk pemodelan dengan cara 2 diperoleh elevasi muka air sebesar +255.99. Sementara untuk hasil perhitungan analitis tinggi muka air waduk berada pada elevasi +256.65(Q1000), dengan begitu maka selisih antara hasil perhitungan analitis dengan pemodelan menggunakan HECRAS tidak jauh berbeda. Salah satu kelebihan perencanaan desain hidraulik bendungan menggunakan software HEC-RAS adalah apabila terdapat alternatif desain baru maka dapat disimulasikan lebih cepat dibandingkan dengan perhitungan analitis.
\end{abstract}

Kata kunci: Bendungan, HEC-RAS, spillway, waduk.

\section{PENDAHULUAN}

Meskipun telah ada kemajuan besar dalam mendesain hidraulik bendungan, akan tetapi diperlukan alternatif lain yang dibutuhkan sebagai pertimbangan dalam mendesain hidraulik Bendungan Tugu. Salah satu alternatif tersebut adalah penggunaan software seperti HEC-RAS. Dengan begitu akan mempermudah dalam merencanakan desain hidraulik Bendungan Tugu. Program HEC-RAS merupakan salah satu program pemodelan analisis hidraulika aliran pada saluran/sungai.
Pada analisis profil muka air pada Bendungan Tugu dilakukan dengan bantuan program HECRAS. Dengan program ini dapat mensimulasikan pola aliran yang ada pada tampungan waduk (hulu) yang dilanjut dengan aliran yang melewati pelimpah (spillway) dan berakhir pada sungai bagian hilir. Simulasi software HEC-RAS bisa digunakan untuk bangunan air sehingga dapat memperkirakan penampang sungai yang tergenang air. Pada kasus ini, pemodelan disimulasikan dengan unsteady flow. Hasil dari pemodelan tersebut berupa daerah genangan, elevasi, kecepatan dan rating curve.

Pemodelan aliran pada Bendungan Tugu perlu dilakukan karena dari hasil pemodelan tersebut dapat memberikan alternatif lain sehingga diharapkan perencanaan desain hidraulik Bendungan Tugu lebih baik.

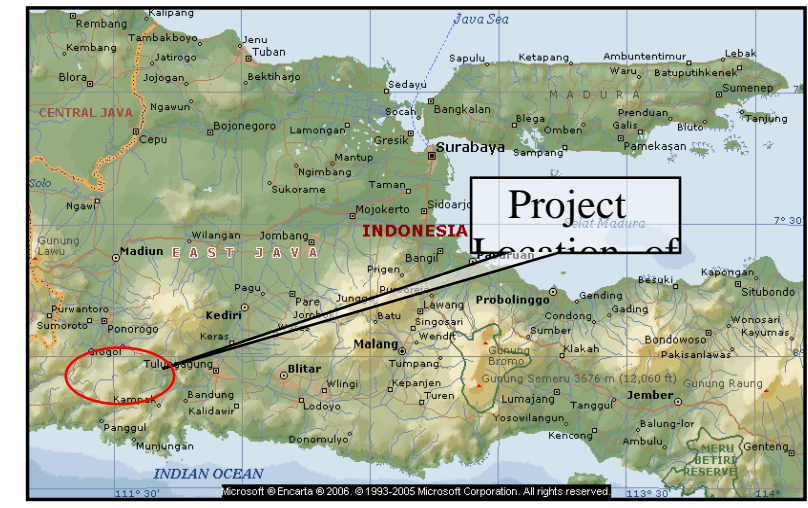

Gambar 1. Lokasi Bendungan Tugu

\section{II.METODE PENELITIAN}

Metodologi yang digunakan dalam pemodelan aliran pada Bendungan Tugu ini adalah sebagai berikut: 
JURNAL HIDROTEKNIK Vol. 2, No. 2, (2017) ISSN : 2477-3212

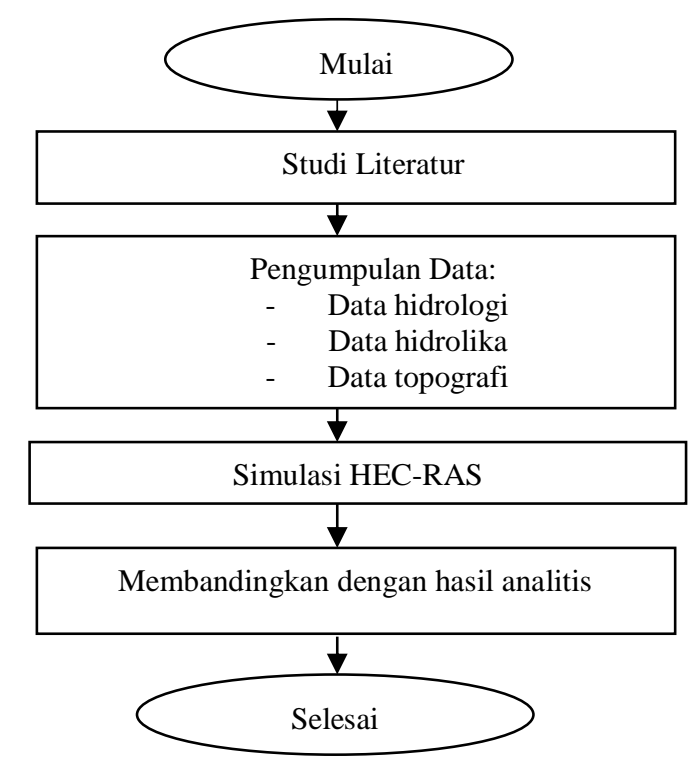

Gambar 2. Diagram Alir Metodologi Perencanaan

\section{HASIL DAN DISKUSI}

\section{E. Parameter HEC-RAS}

Parameter di dalam HEC-RAS digunakan untuk membentuk seri penampang sungai sepanjang saluran sungai. Parameter tersebut terdiri dari:

\section{Data aliran}

Data aliran merupakan data yang dimasukkan untuk pembuatan model hidrologi di dalam HECRAS. Pada pemodelan ini, data aliran yang perlu dimasukkan ke dalam HEC-RAS adalah data debit banjir rancangan metode Nakayasu dengan periode ulang 100 tahun dan 1000 tahun. Data debit banjir yang digunakan berupa debit inflow dan outflow yang sebelumnya telah diperhitungkan oleh konsultan perencana Bendungan Tugu. Debit inflow digunakan ketika memodelkan aliran yang berada dalam waduk, sementara untuk debit outflow digunakan ketika memodelkan profil air yang melewati spillway (Tabel 1).

\section{Geometri sungai}

Penampang melintang sungai merupakan irisan yang memotong daerah dimana dialiri oleh aliran sungai, data ini diperlukan untuk memasukkan data geometri sungai pada HEC-RAS. Geometri sungai didapat dari hasil kontur dengan cara mengubah format .dxf menjadi .xyz menggunakan software DXF2XYZ. Data dengan format .xyz inilah yang dimasukkan ke dalam Global Mapper untuk mendapatkan hasil dari setiap penampang Sungai Keser (Gambar 4).
Tabel 1. Rekapitulasi Debit Inflow dan Outflow

\begin{tabular}{|c|c|c|c|c|}
\hline \multirow{2}{*}{$\begin{array}{c}\text { Waktu } \\
\text { (Jam) }\end{array}$} & \multicolumn{2}{|c|}{ Q100 } & \multicolumn{2}{c|}{ Q1000 } \\
\cline { 2 - 5 } & Qinf & Qout & Qinf & Qout \\
\hline 0 & 0.42 & 0.417 & 0.42 & 0.417 \\
\hline 1 & 42.15 & 23.96 & 76.35 & 43.247 \\
\hline 2 & 335.92 & 119.29 & 610.79 & 245.211 \\
\hline 3 & 368.98 & 272.804 & 670.95 & 532.251 \\
\hline 4 & 335.91 & 326.484 & 610.78 & 609.632 \\
\hline 5 & 289.41 & 314.345 & 526.18 & 573.524 \\
\hline 6 & 214.52 & 267.807 & 389.93 & 480.228 \\
\hline 7 & 152.24 & 208.64 & 276.63 & 367.917 \\
\hline 8 & 111.35 & 157.859 & 202.23 & 274.881 \\
\hline 9 & 83.43 & 119.03 & 151.43 & 207.145 \\
\hline 10 & 64.55 & 92.341 & 117.09 & 159.243 \\
\hline 11 & 50.74 & 73.072 & 91.97 & 124.659 \\
\hline 12 & 40.53 & 58.228 & 73.39 & 99.466 \\
\hline 13 & 32.75 & 46.683 & 59.24 & 80.351 \\
\hline 14 & 26.78 & 39.003 & 48.38 & 66.004 \\
\hline 15 & 21.99 & 32.373 & 39.66 & 54.126 \\
\hline 16 & 18.06 & 26.775 & 32.52 & 44.883 \\
\hline 17 & 14.86 & 22.1 & 26.69 & 37.959 \\
\hline 18 & 12.23 & 18.222 & 21.91 & 31.776 \\
\hline 19 & 10.08 & 15.726 & 18.00 & 26.249 \\
\hline 20 & 8.33 & 13.885 & 14.80 & 21.896 \\
\hline 21 & 6.89 & 12.114 & 12.19 & 18.1 \\
\hline 22 & 5.71 & 10.475 & 10.05 & 15.655 \\
\hline 23 & 4.75 & 8.997 & 8.30 & 13.831 \\
\hline 24 & 3.96 & 7.689 & 6.86 & 12.073 \\
\hline
\end{tabular}

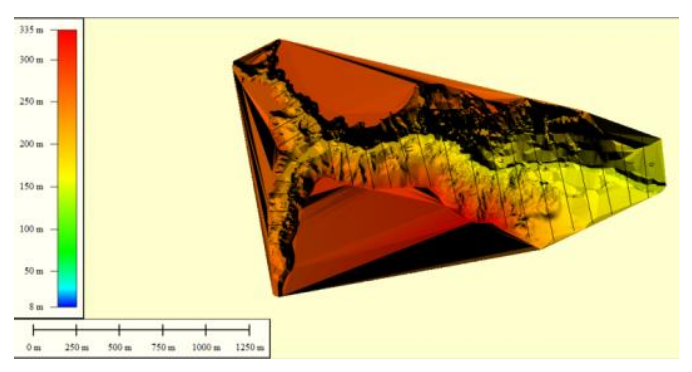

Gambar 3. Kontur Sungai Keser dengan Global Mapper

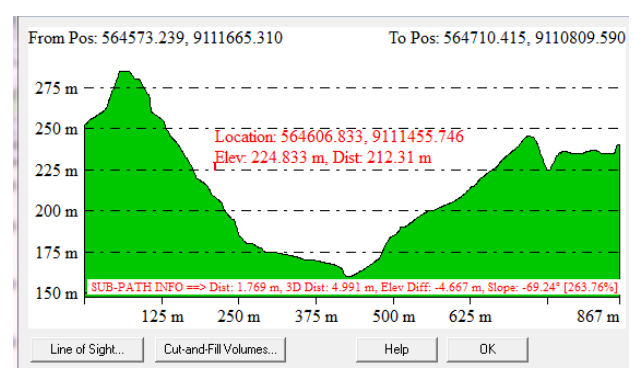

Gambar 4. Hasil Cross Section Salah Satu Penampang

Dari gambar 3 dan gambar 4 diperoleh penampang melintang dari Sungai Keser. Data penampang melintang tersebut nantinya akan dimasukkan ke dalam data geometri HEC-RAS untuk simulasi.

5) Nilai kekasaran Manning

Pada kasus ini, kekasaran Manning sudah di tentukan oleh konsultan perencana Bendungan Tugu sebesar 0.03 pada daerah genangan waduk. 
Dan untuk bangunan pelimpah, kekasaran Manning direncanakan sebesar 0.014 dengan saluran akhir berupa bronjong dengan nilai $\mathrm{n}$ sebesar 0.035 .

\section{A. Pemodelan Waduk dan Bendungan pada HEC-RAS}

HEC-RAS memodelkan bendungan dan waduk dengan dua pilihan cara. Yang dimaksut dengan waduk pada pemodelan disini adalah geometri sungai di daerah genangan, sementara pengertian bendungan pada pemodelan ini adalah aliran air yang melewati outflow pelimpah (ambang pelimpah). Cara 1 yaitu geometri sungai di daerah genangan (waduk) dimodelkan layaknya sebuah alur sungai dengan memodelkan sejumlah river station, sementara bendungan yang berupa outflow pelimpah dimodelkan sebagai inline structure. Yang dimaksut dengan river station pada pemodelan ini adalah potongan melintang sungai di daerah genangan. Cara ke 2 yaitu geometri sungai di daerah genangan (waduk) dimodelkan sebagai storage area dan bendungan yang berupa outflow pelimpah sebagai inline structure.

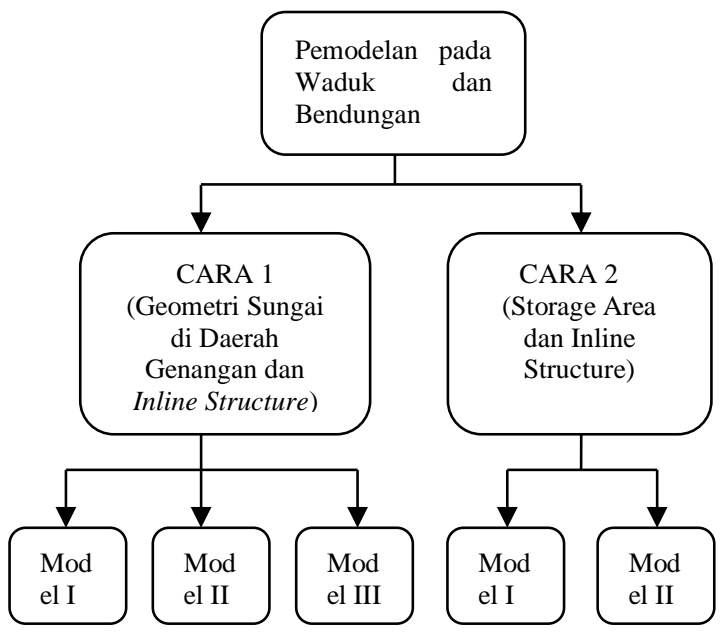

Gambar 5. Skema Pemodelan Waduk dan Bendungan

\section{Pemodelan Cara 1:}

- Pemodelan I (memodelkan geometri sungai di daerah genangan dan ambang pelimpah tetapi tidak memodelkan geometri pelimpah secara detail).

- Pemodelan II (sama dengan pemodelan I, hanya saja adanya penambahan geometri pelimpah secara detail).

- Pemodelan III (hanya memodelkan geometri saluran pelimpah)

Pemodelan Cara 2:

- Pemodelan I (memodelkan geometri sungai di daerah genangan dan ambang pelimpah tetapi tidak memodelkan geometri pelimpah secara detail).

- Pemodelan II (sama dengan pemodelan I, tetapi ada penambahan geometri pelimpah secara detail).
Tahapan dalam memodelkan aliran pada desain hidraulik Bendungan Tugu secara garis besar melalui 4 tahapan, yaitu:

16. Memodelkan geometri

Pada tahapan ini penting untuk memasukkan data geometri sungai, bendungan, ataupun spillway. Selain itu, pada tahap ini nilai kekasaran Manning, elevation dan station, downstream reach length, serta Main Channel Bank Station perlu untuk dimasukkan.

Pemodelan cara 1:

- Pemodelan I. Memasukkan penampang sungai dan bendungan (berupa ambang pelimpah).

- Pemodelan II. Data geometri yang dimasukkan berupa penampang sungai, bendungan (berupa ambang pelimpah) dan spillway.

- Pemodelan III. Penampang saluran pelimpah yang dimasukkan untuk geometri data HEC-RAS.

- Pemodelan cara 2:

- Pemodelan I. Memasukkan penampang sungai dan bendungan (berupa ambang pelimpah)..

- Pemodelan II. Data geometri yang dimasukkan berupa penampang sungai, bendungan (berupa ambang pelimpah) dan spillway.

17. Memodelkan aliran (unsteady flow data)

Untuk memodelkan aliran maka perlu memasukkan data boundary condition (hulu dan hilir) dan data initial condition pada masing-masing pemodelan memiliki kondisi batas dan kondisi awal yang berbeda. Penggunaan kondisi batas dan kondisi awal dapat dilihat pada tabel 2 .

Tabel 2. Kondisi Batas dan Kondisi Awal

\begin{tabular}{|c|c|c|c|c|c|c|}
\hline \multirow{2}{*}{ PEMODELAN } & \multicolumn{2}{|c|}{ BOUNDARY CONDITION } & \multicolumn{3}{|c|}{ INITIAL CONDITION } \\
\cline { 3 - 6 } \multicolumn{2}{|c|}{} & \multirow{2}{*}{ Upstream } & \multirow{2}{*}{ Downstream } & \multicolumn{2}{|c|}{ Initial Flow } & \multirow{2}{*}{ Initial Elevation } \\
\cline { 5 - 6 } & & & Upstream & Junction & \\
\hline \multirow{3}{*}{ CARA 1} & Pem. I & Flow Hydro. & Normal Depth & 2.004 & 3.4 & - \\
\cline { 2 - 6 } & Pem. II & Flow Hydro. & Stage Hydro. & 34.05 & 45.87 & - \\
\cline { 2 - 5 } & Pem. III & Flow Hydro. & Stage Hydro. & 1.13 & - & - \\
\hline \multirow{2}{*}{ CARA 2} & Pem. I & Lateral Inflo. & Stage Hydro. & 76.35 & - & 252 \\
\cline { 2 - 5 } & Pem. II & Lateral Inflo. & Stage Hydro. & 139.4 & - & 256 \\
\hline
\end{tabular}

18. Melakukan simulasi

Mengaktifkan layar hitungan aliran tak permanen dengan memilih menu Run | Unsteady Flow Analysis. Jika pemodelan berhasil maka pada layar proses hitungan akan tampak baris-baris hitungan untuk Geometry Preprocessor, Unsteady Flow Simulation, dan Post Processor berwarna biru.

\section{Menampilkan hasil simulasi}

Menampilkan hasil perhitungan dapat dilakukan dengan cara mengklik tombol view cross section, view profil, view general profil plot, view computed rating curve, view 3D multiple cross

\section{F. Tahap Pemodelan dengan HEC-RAS}


JURNAL HIDROTEKNIK Vol. 2, No. 2, (2017) ISSN : 2477-3212

section plot, etc. Hasil simulasi tersaji dalam gambar 6 - gambar 18.

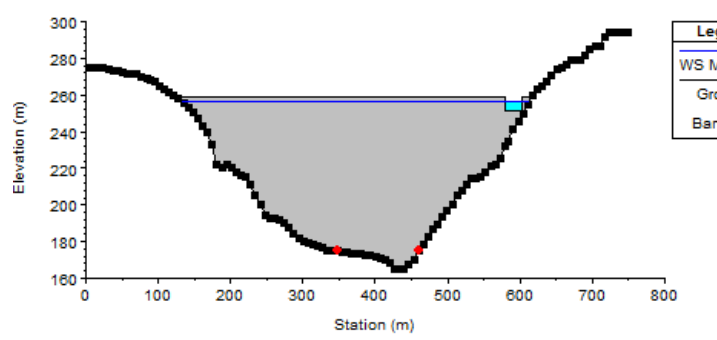

Gambar 6. Cross Section Bendungan pada Pemodelan Cara 1 (Model I)
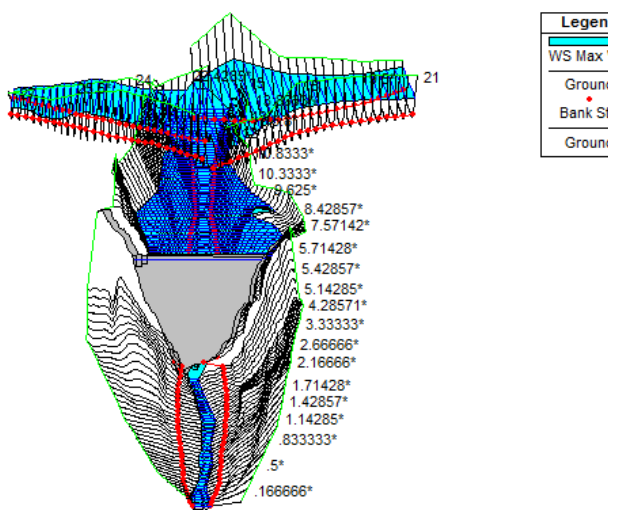

Gambar 7. Plot Prespektif pada Pemodelan Cara 1 (Model I)

Penampang melintang bendungan terlihat seperti gambar 6 dan gambar 7, dimana elevasi puncak bendungan berada pada +259.00 . Sementara untuk tinggi muka air waduk dengan pemodelan I (cara 1) berada pada elevasi +256.07 .

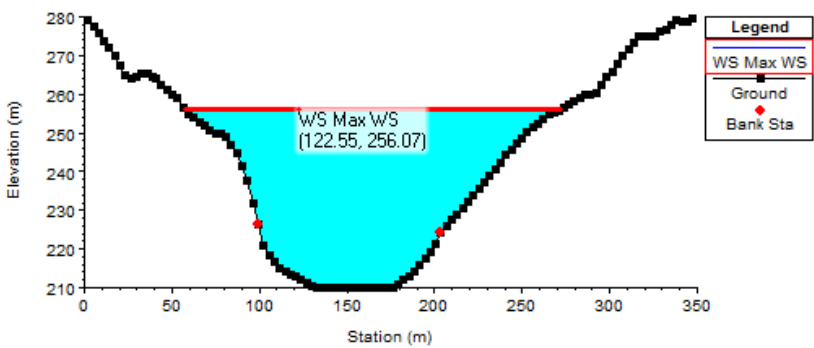

Gambar 8. Cross Section di RS 15 (Upstream) pada Pemodelan Cara 1 (Model II)

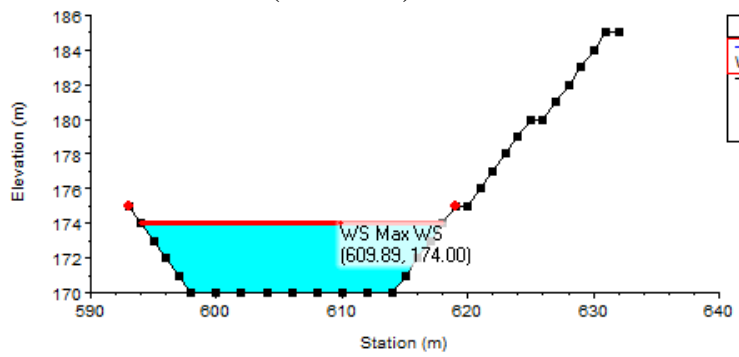

Gambar 9. Cross Section di RS 4.2 (Downstream) pada Pemodelan Cara 1 (Model II)

Hasil dari pemodelan II dengan cara 1 diperoleh tinggi muka air pada waduk (hulu) sebesar +256.07 (Gambar 8), dan untuk bagian hilir saluran pelimpah elevasi muka air berada pada +174.00 (Gambar 9).

Berikut merupakan stage dan Flow Hydrograph dari hasil simulasi pemodelan II dengan cara 1. Garis berwarna biru merupakan stage dan garis merah menggambarkan flow (Gambar 10).

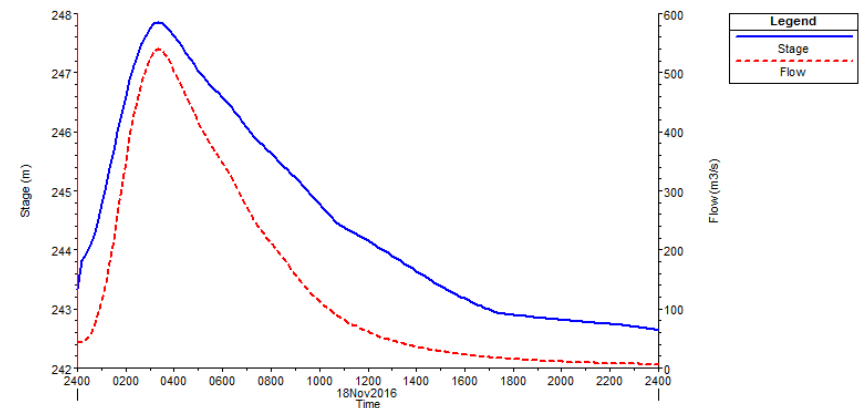

Gambar 10.Stage dan Flow Hydrograph di RS 6.7 pada Pemodelan Cara 1 (Model II)

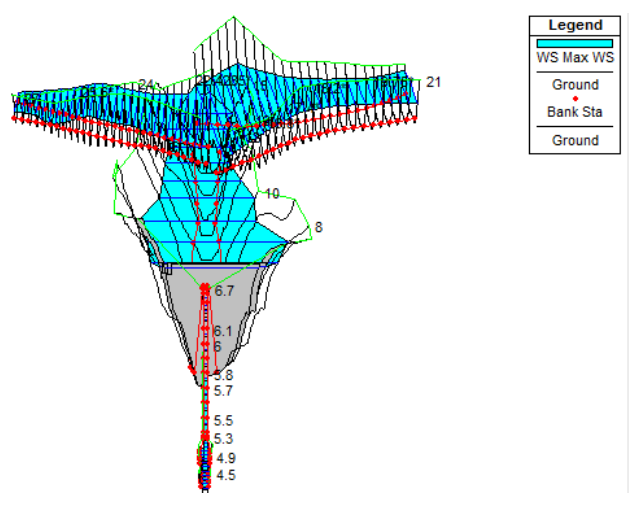

Gambar 11. Plot Prespektif pada Pemodelan Cara 1 (Model II)

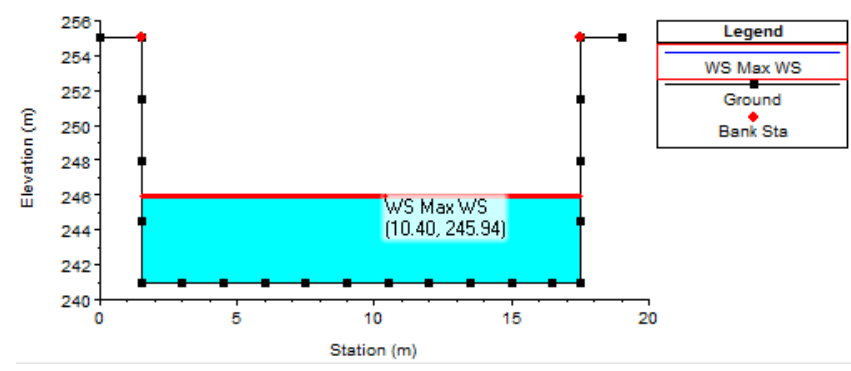

Gambar 12. Cross Section di Saluran Pengarah (RS 24) pada Pemodelan Cara 1 (Model III)

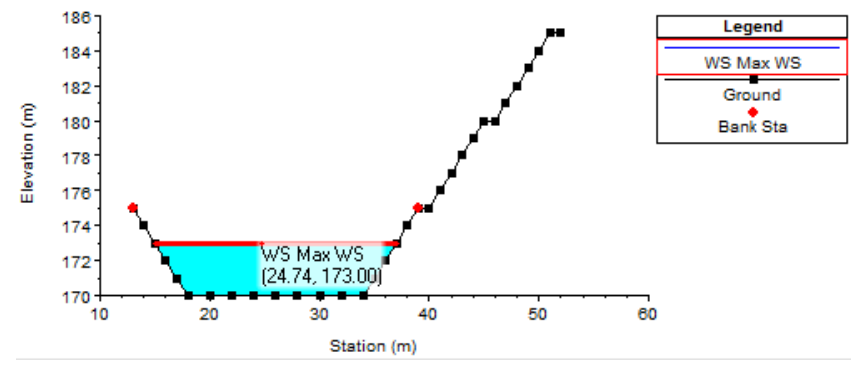


Gambar 13. Cross Section di RS 0 (Downstream) pada Pemodelan Cara 1 (Model III)

Hasil dari pemodelan III dengan cara 1 menghasilkan tinggi muka air pada salah satu titik di saluran pengarah sebesar +245.94 (Gambar 12). Sementara tinggi muka air pada daerah hilir yaitu +173 (Gambar 13) untuk debit periode ulang 1000 tahun.
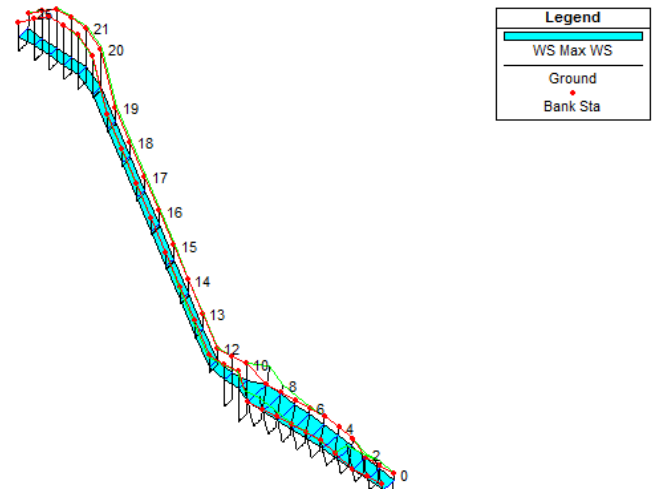

Gambar 14. Plot Prespektif pada Pemodelan Cara 1 (Model III)

Berikut merupakan skema geometri waduk digambarkan sebagai storage area yang berwarna biru, dan bendungan digambarkan sebagai inline structure (lingkaran hitam) sementara hilir sungai digambarkan sebagi river station (Gambar 15).

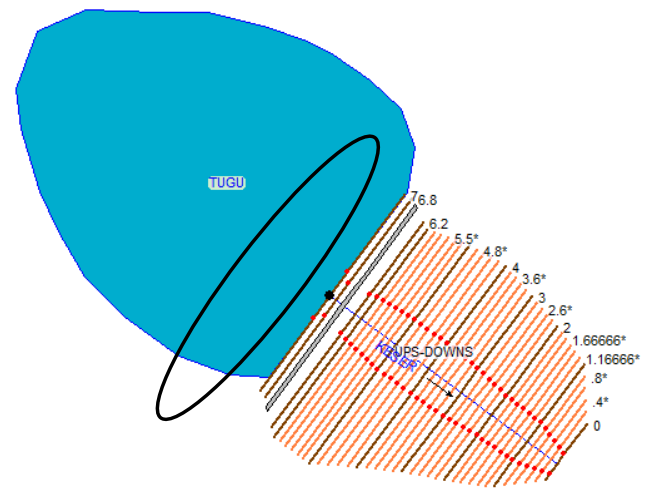

Gambar 15. Skema Geometri pada Cara 2 (Model I)

Hasil simulasi dengan debit periode ulang 1000 tahun menghasilkan tinggi muka air pada daerah hilir sungai sebesar + 153.00. (Gambar 16).

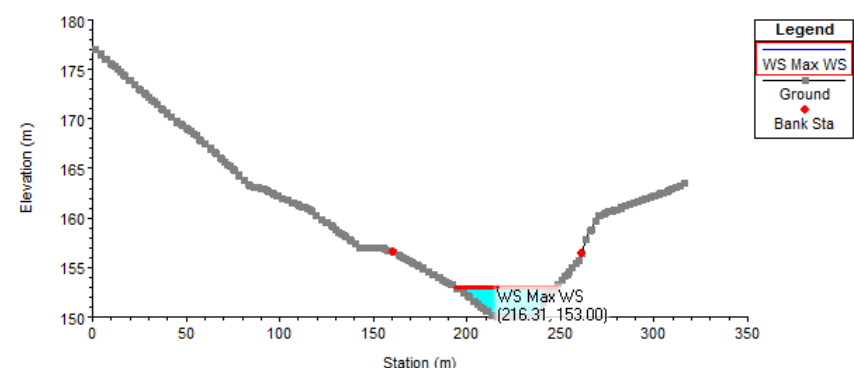

Gambar 16. Cross Section di Downstream pada Pemodelan Cara 2 (Model I)

Hasil simulasi pemodelan I dengan cara 2 menunjukan aliran keluar waduk (outflow) lebih besar daripada inflow, sehingga debit netto bernilai negatif pada 2 jam pertama. Mulai dari jam ke 3 dan seterusnya inflow lebih besar daripada outflow sehingga debit netto bernilai positif (Gambar 17).

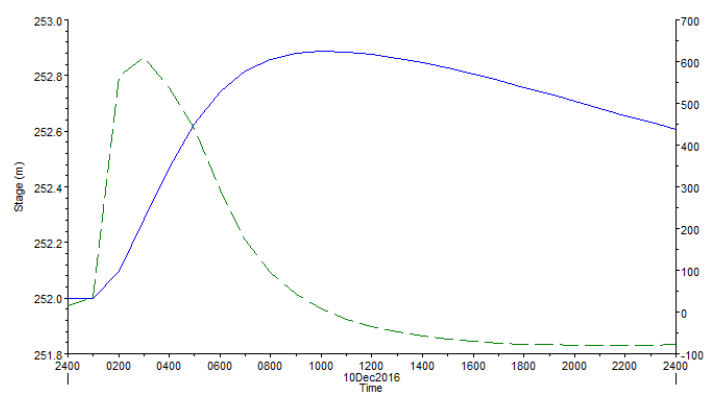

Gambar 17. Stage and Flow Hydrograph di Waduk pada Pemodelan Cara 2 (Model I)

Dari hasil pemodelan II dengan cara 2 menghasilkan tinggi muka air daerah hilir sebesar +173.00 dengan debit periode ulang 1000 tahun (Gambar 18).

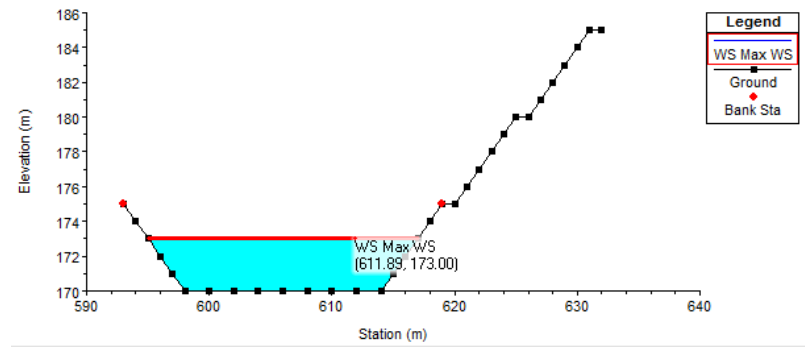

Gambar 18. Cross Section di RS 4 (Downstream) Waduk pada Pemodelan Cara 2 (Model II)

\section{G. Perbandingan Hasil HEC-RAS dengan Hasil Analitis}

Dari beberapa pemodelan yang telah dilakukan menghasilkan profil muka air dari pemodelan HEC-RAS memiliki tinggi muka air yang lebih rendah dibandingkan dengan perhitungan analitis. Hasil perbandingan antara simulasi HEC-RAS dengan hasil perhitungan analitis terdapat pada 
tabel 3 untuk pemodelan cara 1 dan tabel 4 untuk pemodelan cara 2.

Tabel 3. Hasil Perbandingan Pemodelan Cara 1 dengan Perhitungan Analitis

\begin{tabular}{|c|c|c|c|c|c|}
\hline \multicolumn{6}{|c|}{ PEMODELAN CARA 1 (RIVER STATION DAN INLINE STRUCTURE) } \\
\hline \multirow{3}{*}{ SECTION } & \multirow{3}{*}{ PEMODELAN } & \multirow{2}{*}{\multicolumn{2}{|c|}{$\begin{array}{c}\text { HASIL ANALISIS } \\
\text { ELEVASI MUKA AIR (m) }\end{array}$}} & \multirow{2}{*}{\multicolumn{2}{|c|}{$\begin{array}{c}\text { HASIL HEC-RAS } \\
\text { ELEVASI MUKA AIR (m }\end{array}$}} \\
\hline & & & & & \\
\hline & & Q100 & $\mathrm{Q} 1000$ & Q100 & $\mathrm{Q} 1000$ \\
\hline \multirow{2}{*}{ Waduk } & I & 254.685 & 256.65 & 254.44 & 256.07 \\
\hline & II & 254.685 & 256.65 & 254.46 & 256.07 \\
\hline \multirow{2}{*}{ Saluran Transisi } & II & 247.5 & 249.5 & 246.03 & 247.36 \\
\hline & III & 247.5 & 249.5 & 245.14 & 245.94 \\
\hline \multirow{6}{*}{ Saluran Peluncur } & \multirow{3}{*}{ II } & 228.8 & 229.5 & 225.55 & 226.02 \\
\hline & & 208.9 & 209.8 & 208.89 & 209.37 \\
\hline & & 192.8 & 193 & 192.22 & 192.73 \\
\hline & \multirow{3}{*}{ III } & 228.8 & 229.5 & 225.22 & 225.54 \\
\hline & & 208.9 & 209.8 & 208.55 & 208.89 \\
\hline & & 192.8 & 193 & 191.85 & 192.22 \\
\hline \multirow{2}{*}{ Kolam Olak } & II & 176.342 & - & 174.68 & 175.35 \\
\hline & III & 176.342 & - & 174.28 & 175.17 \\
\hline
\end{tabular}

Tabel 4. Hasil Perbandingan Pemodelan Cara 2 dengan Perhitungan Analitis

\begin{tabular}{|c|c|c|c}
\hline \multicolumn{4}{c}{ PEMODELAN CARA 2 (STORAGE AREA DAN INLINE STRUCTURE) } \\
\hline \multirow{2}{*}{ SECTION } & \multirow{2}{*}{ PEMODELAN } & $\begin{array}{c}\text { HASIL ANALISIS } \\
\text { ELVASI MUKA AIR } \\
\text { (Q1000 TAHUN) }\end{array}$ & $\begin{array}{c}\text { ELEVASI MUKA AIR } \\
\text { (Q1000 TAHUN) }\end{array}$ \\
\hline \multirow{2}{*}{ Waduk } & I & 256.65 & 252.89 \\
\cline { 2 - 4 } & II & 256.65 & 255.99 \\
\hline Saluran Transisi & II & 249.5 & 247.77 \\
\hline \multirow{3}{*}{ Saluran Peluncur } & \multirow{2}{*}{ II } & 229.5 & 225.99 \\
\cline { 3 - 4 } & & 209.8 & 209.33 \\
\hline Kolam Olak & II & 193 & 192.67 \\
\hline
\end{tabular}

\section{KESIMPULAN}

1. Berikut merupakan pemodelan yang digunakan untuk memodelkan aliran 1D pada desain Bendungan Tugu menggunakan program HECRAS yaitu:

a. Pemodelan cara 1 yang memodelkan waduk sebagai river station dan bendungan sebagai inline structure. Pada pemodelan ini dapat dimodelkan menjadi beberapa pemodelan yaitu:

- Pemodelan I (memodelkan geometri sungai di daerah genangan dan ambang pelimpah tetapi tidak memodelkan geometri pelimpah secara detail)

- Pemodelan II (sama dengan pemodelan I, hanya saja adanya penambahan geometri pelimpah secara detail)

- Pemodelan III (hanya memodelkan geometri saluran pelimpah)

b. Pemodelan cara 2 yang memodelkan waduk sebagai storage area dan bendungan sebagai inline structure. Pemodelan ini dapat dimodelkan menjadi:

- Pemodelan I (memodelkan geometri sungai di daerah genangan dan ambang pelimpah tetapi tidak memodelkan geometri pelimpah secara detail)

- Pemodelan II (sama dengan pemodelan I, hanya saja adanya penambahan geometri pelimpah secara detail)

2. Hasil dari beberapa pemodelan yang dilakukan untuk memodelkan aliran 1D pada Bendungan Tugu menghasilkan elevasi profil muka air yang lebih rendah dibanding dengan perhitungan analitis. Hal ini dikarenakan pada perhitungan analitis menggunakan perhitungan aliran dengan konsep steady flow yang memasukkan data debit maksimal. Berbeda dengan perhitungan aliran dengan HEC-RAS yang menggunakan unsteady flow sehingga debit yang dimasukkan berupa debit dengan sekala waktu.

3. Kelemahan desain hidraulik Bendungan Tugu menggunakan program HEC-RAS :

- Pada analisa unsteady flow HEC-RAS tidak dapat melakukan simulasi sungai dalam kondisi aliran dasar dengan nilai debit yang kecil (Q mendekati $0 \mathrm{~m}^{3} / \mathrm{dt}$ ).

- Hanya bisa melakukan analisis 1 dimensi.

- Dalam mendesain hidraulik bendungan menggunakan software HEC-RAS diperlukan data yang lebih lengkap dibanding dengan perencanaan analitis.

4. Kelebihan desain hidraulik Bendungan Tugu menggunakan program HEC-RAS :

- Memiliki hasil akurasi yang cukup baik.

- Distribusi debit setiap cross section dapat diketahui secara langsung setelah simulasi.

- Untuk mendesain hidraulik bendungan menggunakan software HEC-RAS apabila terdapat alternatif desain baru maka dapat disimulasikan lebih cepat dibandingkan dengan perhitungan analitis.

\section{DAFTAR PUSTAKA}

[1] Dep. PU Balai Besar Wilayah Sungai Brantas Surabaya. 2010. Laporan Akhir Pekerjaan Proyek Pembangunan Bendungan Tugu. Kabupaten Trenggalek.

[2] Hydrologic Engineering Center. 2010. HECRAS River Analysis System, Hydraulic Reference Manual, Version 4.1.0, January 2010. U.S. Army Cormps of Engineers, Davis, CA.

[3] Istiarto. 2014. Simulasi Aliran 1-Dimensi Dengan Bantuan Paket Program 
JURNAL HIDROTEKNIK Vol. 2, No. 2, (2017) ISSN : 2477-3212

Hidrodinamika Hec-Ras. Modul Pelatihan Simple Geometry River. Yogyakarta.

[4] Hydrologic Engineering Center. 2010. HECRAS River Analysis System, User's Manual, Version 4.1.0, January 2010. U.S. Army Cormps of Engineers, Davis, CA.

[5] Istiarto. 2014. Simulasi Aliran 1-Dimensi Dengan Bantuan Paket Program Hidrodinamika Hec-Ras. Junction and Inline Structures. Yogyakarta.

[6] Istiarto. 2014. Simulasi Aliran 1-Dimensi Dengan Bantuan Paket Program Hidrodinamika Hec-Ras. Lateral Structure, Storage Area, and Pump Station. Yogyakarta. 